\title{
PRELIMINARY GEOLOGIC MAP OF THE VALDEZ-TIEKEL BELT, ALASKA \\ By
}

H. W. Coulter and E. B. Coulter
MISCELLANEOUS GEOLOGIC INVESTIGATIONS
MAP I-356

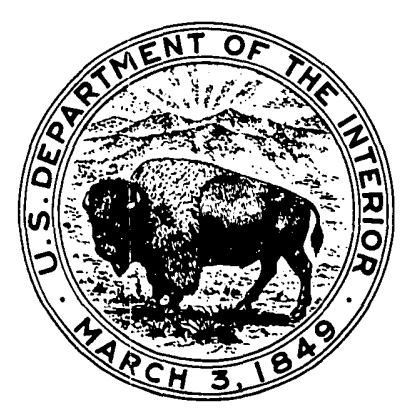

